\title{
Durability of Asphalt Concrete (ACWC) Mixed with Antistripping Additive
}

\author{
Sena Kuswara, Bagus Hario Setiadji, Jati Utomo Dwi Hatmoko
}

\begin{abstract}
In pavement structures that are often submerged by water, the damage to pavement is often caused by the loss of bonds or adhesions between the aggregate and asphalt, the type of damage that occurs due to the loss of adhesion between the aggregate and asphalt is the exfoliation of asphalt granules so that the road is cracked and corrugated. To reduce the release of aggregate granules and improve the bond between aggregates and asphalt can be made with the addition of anti-exfoliating additives or antistripping agent additives. This study aims to analyze the performance of wear-coated concrete asphalt mixture (ACWC) with the addition of antistripping additives. Antistripping agents used in this study were Zycotherm, Morlife and Adhebit with variations of $0.1 \%$ addition, $0.3 \%$ and $0.5 \%$ of the weight of asphalt mixture. The results of this study showed that ACWC mixture with the addition of Zycotherm additives resulted in optimum Marshall stability and increased durability at $0.5 \%$ and Adhebit additives at $0.3 \%$ levels, while in Morlife additives although at $0.3 \%$ levels were able to show optimum marshall analysis in terms of increased durability did not show expected performance.
\end{abstract}

Keywords : Antistripping Additive, Asphalt Concrete Wearing Course, Durability, Marshall Parameters.

\section{INTRODUCTION}

The problem that often occurs in road structures in tropical climates is when the dry season is exposed to high heat and during the rainy season most of the roads are submerged. One of the parmeters of hot asphalt mixture performance is resistance due to the influence of weather and water (durability), pavement structures that are always submerged by water will experience a decrease in durability. The common damage caused by submerged road structures is the exfoliation of asphalt granules so that the road is cracked and corrugated. One way to avoid exfoliating asphalt is to add antistripping additives that serve to improve the quality of aggregate and asphalt bonding. The condition of the tendency to exfoliate the paved mixture or moisture susceptibility is a

Manuscript received on March 04, 2021.

Revised Manuscript received on March 08, 2021.

Manuscript published on April 30, 2021.

* Correspondence Author

Sena Kuswara*, Master Program of Civil Engineering, Diponegoro University, Semarang, Indonesia. Email: senokusworo@yahoo.com

Bagus Hario Setiadji, Doctor, Highway Engineering, National University of Singapore.

Jati Utomo Dwi Hatmoko, Doctor, Civil Engineering, Newcastle University, UK.

(C) The Authors. Published by Blue Eyes Intelligence Engineering and Sciences Publication (BEIESP). This is an open access article under the CC BY-NC-ND license (http://creativecommons.org/licenses/by-nc-nd/4.0/) condition where the loss of integrity and weakening of the bond between the aggregate and the binding structure of a paved mixture. Exfoliation begins at the bottom of the asphalt mixture layer and gradually moves towards the upper layer if the condition is left for years then on the surface will arise folds, waves, raveling, and cracking. The above conditions can be overcome with the help of anti-exfoliating additives. Anti-exfoliating additives when added to asphalt mixtures can replace moisture on the surface of aggregate adhesions and produce bonds on aggregate surfaces (Sembiring and Muis, 2013).

Antistripping Agent is an additive that is added to the asphalt mixture that has various functions, among others, changing the properties of asphalt and aggregate, increasing adhesions and bonds, and reducing the negative effects of water that can cause moisture resulting in a high-adhesed surface. The benefits of adding additives are expected to minimize the occurrence of road damage by direct touch with the wheels of vehicles and hot and rainy weather so as to extend the life of road pavement and improve the quality of road pavement structures (Aminsyah, M,.2014).

Asphalt concrete (ACWC) is a pavement layer consisting of a mixture of hard asphalt and aggregate, then mixed and spread out in a hot state and compacted at a certain temperature (Sukirman,1999). Laston besides is a layer of wear (layers that are directly related to vehicle load) also has a structure function because it has a high structural strength value and serves as a protector of construction under it from the influence of water and weather (Aminsyah, M,.2014)

Zycotherm is a WMA additive for hotmix mixtures developed by Zydex Industries, Gujarat, India. The use of anti-exfoliating additives of this type of Zycotherm ranges from $0.1 \%-0.4 \%$ of the weight of bitumen to hot asphalt mixtures, while for road repairs its use ranges from $0.2 \%-0.5 \%$ of the weight of asphalt bitumen.

Morlife 300 antistripping additive can increase the bond between asphalt and aggregate on hot asphalt mixtures and overcome problems associated with poor adhesion. The Hotmix mixture with the addition of the Morlife 300 additive shows increased resistance to moisture-related damage and stripping, resulting in more durable pavement.

Adhebit S-102 is one of the antistripping additives produced using nanotechnology. Nanoparticles contain only a few atoms to hundreds of atoms. It affects their characteristics. In particular, nanoparticles react differently to other elements. By reducing particle size, surface area increases and more atoms are available to interact with atoms or other ions of other substances.

Published By:

Blue Eyes Intelligence Engineering and Sciences Publication 
The use of Adhebit S-102 has the following benefits of promoting bitumen/aggregate, ensuring perfect status between Bitumen and Aggregate, increasing asphalt water resistance and small doses $(0.05 \%-0.2 \%$ on binder weight).

Research using wetfix BE antistripping additives on superpave graded hot asphalt mixtures, with Marshall method test results showed that hot asphalt mixture using Wetfix BE additives experienced a decrease in quality compared to hot asphalt mixtures without additives that is with increased VMA and VFA decrease, stability value decreased but still within the requirement range. Meanwhile, the remaining marshall stability value increased by $6.72 \%$ at Wetfix BE level of $0.3 \%$. With the conclusion of the use of Wetfix BE does not fully improve the characteristics of marshals (Rizal et al., 2019).

The addition of antistripping additives is able to prevent exfoliation of aggregates and asphalt even in submerged conditions and increase durability in hot asphalt mixtures with the increasing stability value of hot asphalt mixtures with the addition of antistripping additives (Christopper et al., 2016). While Ruslan et al (2016) concluded that the addition of antistripping additives in ACBC with a content of $0.35 \%$ is able to increase stability value with a value of $858.52 \%$ and the stability value of the remaining mixture with a value of 94.558\% compared to ACBC without additives which means the addition of antistripping additives is able to increase the durability or durability of hot asphalt mixtures.

Jaya et al (2013) in his research concluded the influence of the addition of Wetfix Be additives on hot asphalt mixture stability values tend to fall which means it can not add strength to the mixture, lower the flow value, increase the VMA value but lower the VFA value. While in the immersion test results the addition of Wetfix BE additives in the WC HRS layer mixture is able to increase the bond between asphalt and aggregate, and improve Marshall Stability Time higher than HRS WC without additives. Sawaludin et al (2017) stated that the addition of antistripping additives in the WC HRS mixture was able to increase the residual marshall stability value of the rest of the WC HRS without additives worth $90.30 \%$ to $91.29 \%$ after the addition of antistripping additives which means antistripping additives are able to increase the durability of the mixture.

The addition of antistripping additives is able to increase the durability or durability of the mixture by $4.64 \%$ compared to hot asphalt mixtures without additives which means that the concrete asphalt mixture is more resistant to damage due to exfoliation due to weather and the influence of water soaking. Sembiring and Muis (2014) in laboratory experiments concluded that $60 / 70$ penetration asphalt testing with variations in antistripping additions showed different marshall testing parameters especially on residual Marshall Stability values where wetfix BE additives at an additional rate of $0.5 \%$ had an IRS value of $9.641 \%$ higher compared to derbo-401 and Morlife 2200 additives (Aminsyah, M,.2014).

Tahir and Setiawan (2009) stated that the Residual Strength Index Value (IKS) decreased in line with the length of immersion. The First Durability Index (IDP) and the Second Durability Index (IDK) generally experience a loss of strength in line with the addition of the soaking length except on the 4th day soaking indicating increased strength.

The difference in this research with previous research is the Marshall Soaking Modification method for durability testing,

this is related to the Marshall Immersion soaking test is often not quite right describing the actual decrease in durability in the field. Another thing that is different is the use of different types of antistripping additives, the specifications of hot asphalt mixtures updated with the latest technical specifications are expected to obtain newness test results that are more accurate and scientifically accountable.

The purpose of this study was to find out the performance and durability of hot asphalt mixture (ACWC) with the addition of antistripping additives with additives Zycotherm, Morlife 300 and Adhebit S-102, as a comparison used hot asphalt mixture (ACWC) without the addition of antistripping additives.

\section{RESEARCH METHODS}

The stages of this research activity begin with the preparation of laboratory equipment and materials to be used, then carried out testing of materials to ensure all materials used meet the requirements. The next stage of making test objects both ACWC test objects without additives and ACWC test objects with antistripping additives to be carried out Standard Marshall testing, Immersion Marshall Test and Modified Soaking Test. The research was conducted in the laboratory of Pulogadung Asphalt Mixing Plant (AMP) Unit of PT Jaya Konstruksi MP. Testing with the Marshall Method based on hot paved mix planning guidelines refers to the standard guidelines of the Ministry of Public Works and Public Housing, Methods, Specifications and Procedures section 6.3: Heat Paved Mixture from the Directorate General of Highways (2018).

\section{A. Marshall Method}

Marshall Method testing follows AASHTO T245-97 procedure with the aim of obtaining test objects that have properties such as: stability, flow ( melting rate), cavities in the mixture (VIM), asphalt filled cavities (VFA), and cavities in aggregat (VMA).

\section{B. Marshall Soaking Test}

In the Marshall Method the immersion of the test object is carried out by 2 methods namely the first method of the test object is soaked at a temperature of $60^{\circ} \mathrm{C}$ for 30 minutes and the second method of the test object is soaked at a temperature of $60^{\circ} \mathrm{C}$ for 24 hours. From the soaking method above will be obtained the result of comparison of stability of soaked test objects with standard stability then expressed as percent and called Time Stability Index (IRS), calculated by the following formula.

$$
I R S=\left[\frac{M S i}{M S s}\right] \times 100 \%
$$

Description:

IRS = Index of Retained Strength

MSi = Marshall stability conditions after soaking for 24

hours with a temperature of $60^{\circ} \mathrm{C}$

MSs = Marshall Stability in Standard Conditions

\section{Modified Marshall Soaking Test}

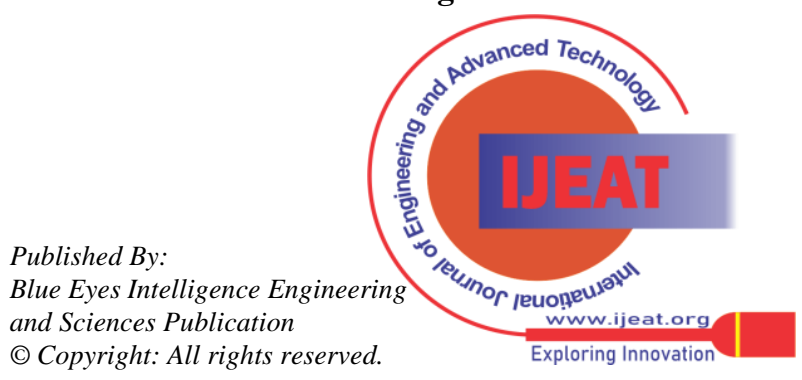


Immersion test object test is done with soaking duration of 1,3 , and 7 days at room temperature, from Marshall test can be measured First Durability Index (IDP) and Second Durability Index (IDK) as follows:

- First Durability Index

The First Durability Index is the sequential number of durability curves (Craus et al in Basir and Ramli, 2005).

$$
\mathrm{r}=\sum \frac{S i-S i+1}{T i+1-T i}
$$

\section{Description:}

$r=$ First durability index $(\%)$

$\mathrm{T}=$ Soaking time (days)

$\mathrm{S}=$ Stability

\section{- Second Durability Index}

The second durability index is the area of average strength loss between the durability curve and the So line $=100 \%$. The second durability index can be expressed as a condition of loss of strength in one day, where the positive value of (a) indicates loss of strength, while the negative value means the opposite (Craus et al in Basir and Ramli, 2005). This index (a) is calculated by the following formula:

$a=\frac{1}{t_{n}} \sum_{t=1}^{n} a_{1}$

$$
=\frac{1}{2 t_{n}} \sum_{t=0}^{n-1}\left(S_{i}-S_{i+1}\right)\left[2 t_{n}-\left(t_{i+1}+t_{i+1}\right)\right]
$$

Description:

$\mathrm{a}=$ Second durability index

$\mathrm{S}=$ Stability

$\mathrm{t}=$ Soaking time (days)

\section{RESULTS AND DISCUSSION}

\section{A. Aggregate Physical Testing Results}

The results of aggregate physical properties testing that have been done in the laboratory can be seen in Table 1 .

From Table 1 it can be concluded that both crude and fine aggregates meet the requirements of the General Specification of Road and Bridge 2018.

\section{B. Asphalt Physical Testing Results}

The asphalt used in this study used asphalt with a penetration of 60/70, the results of asphalt testing are shown in Table 2.

From Table 2, the $60 / 70$ penetration asphalt meets the General Specifications of Road and Bridge in 2018.

\section{Asphalt + Additive Physical Testing Results}

Examination is carried out on the physical properties of asphalt penetration 60/70 ex Pertamina products plus antistripping additives to meet the General Specifications of Road and Bridge 2018, the test results are presented in Table 3.

\begin{tabular}{|c|c|c|c|c|c|c|}
\hline \multirow[b]{2}{*}{ No } & \multirow[b]{2}{*}{ Properties } & \multirow[b]{2}{*}{ Unit } & \multicolumn{2}{|c|}{ Specifications } & \multirow[b]{2}{*}{ Results } & \multirow[b]{2}{*}{ Description } \\
\hline & & & Min & Max & & \\
\hline \multicolumn{7}{|c|}{ Rough Aggregate } \\
\hline 1 & Absorption & $\%$ & & 3 & 2.04 & Qualified \\
\hline 2 & $\begin{array}{l}\text { The immortality of the form against the } \\
\text { solution }\end{array}$ & $\%$ & 12 & 18 & 14.5 & Qualified \\
\hline 3 & \multicolumn{2}{|l|}{ Bulk Unit Weight } & 2.5 & & 2.535 & Qualified \\
\hline 4 & Abrasion Los Angeles & $\%$ & & 40 & 23.28 & Qualified \\
\hline 5 & Flat and Oblong Particles & $\%$ & & 10 & 4.86 & Qualified \\
\hline 6 & Attachment to Asphalt & $\%$ & 95 & & 98.5 & Qualified \\
\hline 7 & Soundness Test & $\%$ & & 7 & 5.26 & Qualified \\
\hline 8 & Broken Items on Coarse Aggregate & $\%$ & 90 & 95 & 93 & Qualified \\
\hline 9 & Material passes filter No.200 & $\%$ & & 1 & 0.114 & Qualified \\
\hline \multicolumn{7}{|c|}{ Fine Aggregate } \\
\hline 1 & Water Absorption & $\%$ & & 3 & 2.15 & Qualified \\
\hline 2 & \multicolumn{2}{|l|}{ Bulk Unit Weight } & 2.5 & & 2.536 & Qualified \\
\hline 3 & \multicolumn{2}{|l|}{ Pseudo Unit Weight } & & & 2.682 & Qualified \\
\hline 4 & \multicolumn{2}{|l|}{ Effective Unit Weight } & & & 2.591 & Qualified \\
\hline 5 & Sand Equivalent Value & $\%$ & 50 & & 77.03 & Qualified \\
\hline 6 & Material passes filter No.200 & $\%$ & & 10 & 9.85 & Qualified \\
\hline \multicolumn{7}{|l|}{ Filler } \\
\hline 1 & Unit Weight & & 1 & & 2.523 & Qualified \\
\hline
\end{tabular}

Table 1 Aggregate Physical Properties Check Results

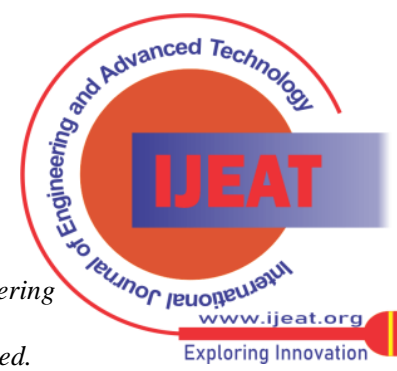


Table 2 Results of Physical Properties of Asphalt Pen 60/70 Ex Pertamina

\begin{tabular}{|c|l|c|c|c|}
\hline No. & \multicolumn{1}{|c|}{ Test Type } & Specifications & $\begin{array}{c}\text { Inspection } \\
\text { Results }\end{array}$ & Description \\
\hline $\mathbf{1}$ & $\begin{array}{l}\text { Penetration at } \\
25^{\circ} \mathrm{C}(0.1 \mathrm{~mm})\end{array}$ & $60-70$ & 68.40 & Qualified \\
\hline $\mathbf{2}$ & $\begin{array}{l}\text { Weight Loss } \\
\left(163^{\circ} \mathrm{C}\right), \%\end{array}$ & Max 0.8 & 0.113 & Qualified \\
\hline $\mathbf{3}$ & $\begin{array}{l}\text { Penetration at } \\
25^{\circ} \mathrm{C} \text { after weight } \\
\text { loss (original \% })\end{array}$ & Min 54 & 87.28 & Qualified \\
\hline $\mathbf{4}$ & Soft Spots $\left({ }^{\circ} \mathrm{C}\right)$ & $\geq 48$ & 48.70 & Qualified \\
\hline $\mathbf{5}$ & $\begin{array}{l}\text { Ductility at } 25^{\circ} \mathrm{C} \\
(\mathrm{cm})\end{array}$ & $\geq 100$ & 137.50 & Qualified \\
\hline $\mathbf{6}$ & Flash Point $\left({ }^{\circ} \mathrm{C}\right)$ & $\geq 232$ & 329.00 & Qualified \\
\hline $\mathbf{7}$ & $\begin{array}{l}\text { Solubility in } \\
\text { Trichloroethylene } \\
(\%)\end{array}$ & $\geq 99$ & 99.40 & Qualified \\
\hline $\mathbf{8}$ & Unit Weight & $\geq 1.0$ & 1.031 & Qualified \\
\hline
\end{tabular}

Table 3 Asphalt + Additive Inspection Results

\begin{tabular}{|c|c|c|c|c|c|}
\hline No & Material & $\begin{array}{l}\text { Penetration at } \\
25^{\circ} \mathrm{C}(0.1 \mathrm{~mm})\end{array}$ & $\begin{array}{l}\text { Soft Spots } \\
\left({ }^{\circ} \mathrm{C}\right)\end{array}$ & $\begin{array}{l}\text { Ductility at } \\
25^{\circ} \mathrm{C}(\mathrm{cm})\end{array}$ & Description \\
\hline & Specifications & $60-70$ & $\geq 48$ & $\geq 100$ & \\
\hline \multirow[t]{2}{*}{1} & Pertamina Asphalt (Pen 60/70) & 65.33 & 49.85 & 137.5 & Qualified \\
\hline & Zycotherm & & & & \\
\hline 1 & Asphalt + $0.1 \%$ Zycotherm & 67 & 49.25 & 134.5 & Qualified \\
\hline 2 & Asphalt + $0.3 \%$ Zycotherm & 68 & 48.75 & 128.5 & Qualified \\
\hline 3 & Asphalt + $0.5 \%$ Zycotherm & 69.11 & 48 & 120.5 & Qualified \\
\hline \multirow[t]{2}{*}{4} & Asphalt + $1.0 \%$ Zycotherm & 70.44 & 47.75 & 112.5 & Unqualified \\
\hline & Morelife & & & & \\
\hline 1 & Asphalt $+0.1 \%$ Morelife & 66.67 & 49 & 131 & Qualified \\
\hline 2 & Asphalt $+0.3 \%$ Morelife & 68.22 & 48.5 & 125 & Qualified \\
\hline 3 & Asphalt $+0.5 \%$ Morelife & 69.44 & 48 & 116 & Qualified \\
\hline \multirow[t]{2}{*}{4} & Asphalt $+1.0 \%$ Morelife & 70.89 & 47 & 105.5 & Unqualified \\
\hline & Adhebit & & & & \\
\hline 1 & Asphalt $+0.1 \%$ Adhebit & 66.33 & 49.2 & 133.5 & Qualified \\
\hline 2 & Asphalt $+0.3 \%$ Adhebit & 67.78 & 48.75 & 128.5 & Qualified \\
\hline 3 & Asphalt $+0.5 \%$ Adhebit & 68.89 & 48 & 118.5 & Qualified \\
\hline 4 & Asphalt + $1.0 \%$ Adhebit & 70.22 & 47.5 & 110 & Unqualified \\
\hline
\end{tabular}

From Table 3 results of testing the physical properties of asphalt +additives can be concluded the addition of qualified penetration of $60 / 70$ is the addition of additives at levels of $0.1 \%, 0.3 \%$ and $0.5 \%$ for all types of antistripping additives.

\section{Determination of Optimum Asphalt Levels}

The test results in the first stage, to find the optimum asphalt content value (KAO) obtained the average value of
Marshall Test characteristics shown in Table 4. From the equation that represents the trendline line in the relationship of Marshall Test characteristics with the asphalt content, it is graphed the relationship of the six marshall parameters with the asphalt content to find optimum asphalt levels that meet the requirements of the six parameter.

Table 4 Copyright Results Marshall Mixed AC WC with Variation of Asphalt Content on (2x75) Collision

\begin{tabular}{|c|l|c|c|c|c|c|c|}
\hline & & \multicolumn{5}{|c|}{ \% Of Asphalt Content to Aggregate Total } \\
\cline { 4 - 8 } No & Mixed Properties & Specifications & $\mathbf{4 . 5}$ & $\mathbf{5}$ & $\mathbf{5 . 5}$ & $\mathbf{6}$ & $\mathbf{6 . 5}$ \\
\hline 1 & Density (gr/cc) & $\min 2$ & 2.406 & 2.398 & 2.389 & 2.372 & 2.356 \\
\hline 2 & VMA (\%) & $\min 15$ & 16.38 & 16.48 & 16.77 & 17.21 & 17.88 \\
\hline 3 & VFA (\%) & $\min 65$ & 64.48 & 68.66 & 72.76 & 75.78 & 77.48 \\
\hline 4 & VIM (\%) & $3-5.0$ & 5.82 & 5.17 & 4.53 & 4.17 & 4.03 \\
\hline
\end{tabular}

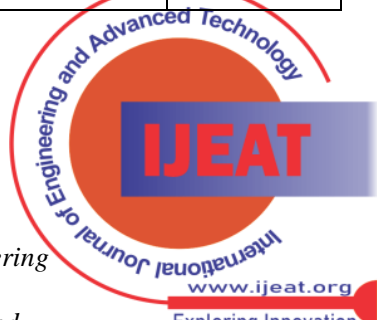




\begin{tabular}{|l|l|c|c|c|c|c|c|}
\hline 5 & Stability $(\mathrm{kg})$ & $\min 800$ & 1,307 & 1,460 & 1,572 & 1,485 & 1,396 \\
\hline 6 & Melting rate $(\mathrm{mm})$ & $02-\mathrm{Apr}$ & 3.277 & 3.446 & 3.615 & 3.954 & 4.123 \\
\hline
\end{tabular}

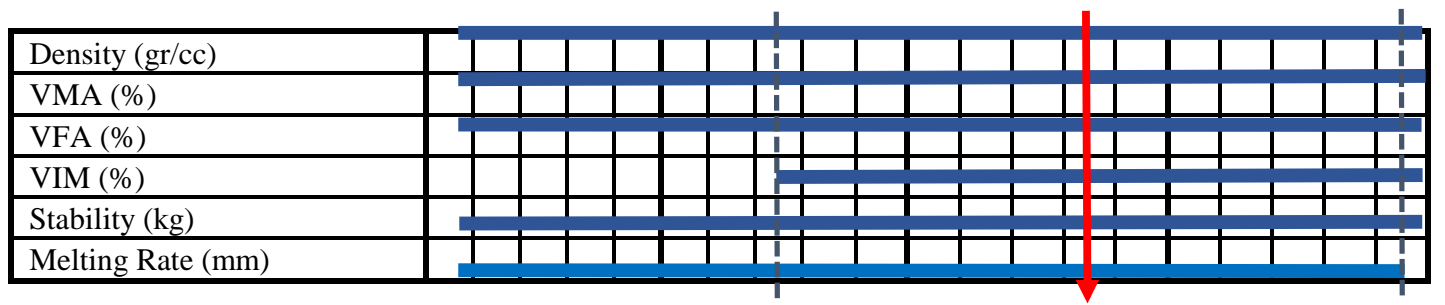

4,5

$$
5,0 \quad 5,15 \quad 5,5
$$

5,8

6,0

6,45

6,5

Optimum Asphalt Content $=(5.15+6.45) / 2=5.80$

Figure 1 Determination of Optimum Asphalt Levels

Table 5 ACWC Marshall Test Results (KAO) 2x75 collisions and 2x400 collisions

\begin{tabular}{|c|l|c|c|c|}
\hline No & \multicolumn{1}{|c|}{ Mixed Properties } & Specifications & $\begin{array}{c}\text { ACWC 2x75 } \\
\text { collision }\end{array}$ & $\begin{array}{c}\text { ACWC 2x400 } \\
\text { collision }\end{array}$ \\
\hline 1 & Density (gr/cc) & $\min 2$ & 2.280 & 2.317 \\
\hline 2 & Cavities in Aggregates (VMMs) (\%) & $\min 15$ & 16.984 & 15.628 \\
\hline 3 & Asphalt Filled Cavity (VFA) (\%) & $\min 65$ & 74.444 & 82.228 \\
\hline 4 & Cavities in the mixture (VIM) (\%) & $3-5.0$ & 4.341 & 2.777 \\
\hline 5 & Marshall Stability (kg) & $\min 800$ & $1,565.85$ & $2,250.40$ \\
\hline 6 & Melting Rate (Flow) (mm) & $2-4$ & 3.780 & 3.277 \\
\hline 7 & $\begin{array}{l}\text { Stability Marshall Time (\%) After soaking } \\
\text { 1x24 hours (60 C) }\end{array}$ & $\min 90$ & 91.861 & - \\
\hline
\end{tabular}

From Figure 1, the optimum asphalt content of ACWC mixture is $5.8 \%$. After the manufacture of test objects using optimum asphalt levels, the next stage will be obtained marshall test characteristics both dry conditions and soaked conditions.

The results of the ACWC Marshall Test with optimum Asphalt Content are shown in Table 5. From the results of the phase III Marshall Refusal Density (2x400 collision) test obtained a VIM value of $2.77 \%$, this value meets the minimum requirement in accordance with the Ministry of PUPR standards (2018) of a minimum of $2 \%$.

\section{E. Marshall Testing on ACWC plus Zycotherm, Morlife and Adhebit Additives}

The next stage is the manufacture of test objects using optimum asphalt content of $5.8 \%$ with the addition of antistripping additives agents Zycotherm, Morlife and Adhebit with variations of $0.1 \%, 0.3 \%$ and $0.5 \%$ of the weight of asphalt mixture. From the experiment will be obtained marshall Test characteristics both dry conditions and soaked conditions. The following table of average values of Marshall parameters include: type weight, stability, flow, VIM, VMA, VFA and Residual Stability. Test data can be seen in Table 6 and Figure 2 below.

Table 6 Average Values of ACWC Marshall Testing with Antistriping Additives Zycotherm

\begin{tabular}{|c|c|c|c|c|c|c|c|c|c|c|c|c|}
\hline \multirow[t]{2}{*}{ No } & \multirow{2}{*}{$\begin{array}{c}\text { Mixed } \\
\text { Properties }\end{array}$} & \multirow[t]{2}{*}{ Spesification } & \multicolumn{4}{|c|}{ ACWC + Zycotherm (\%) } & \multicolumn{3}{|c|}{ ACWC + Morelife (\%) } & \multicolumn{3}{|c|}{ ACWC + Adhebit (\%) } \\
\hline & & & $\mathbf{0}$ & 0.1 & 0.3 & 0.5 & 0.1 & 0.3 & 0.5 & 0.1 & 0.3 & 0.5 \\
\hline 1 & Density (gr/cc) & $\min 2$ & 2.28 & 2.689 & 2.441 & 2.121 & 2.71 & 2.491 & 2.203 & 2.722 & 2.551 & 2.385 \\
\hline 2 & VMA (\%) & $\min 15$ & 16.984 & 16.886 & 16.796 & 16.696 & 16.856 & 16.811 & 16.732 & 16.892 & 16.837 & 16.772 \\
\hline 3 & VFA (\%) & $\min 65$ & 74.444 & 74.968 & 75.447 & 75.994 & 75.124 & 75.369 & 75.797 & 74.934 & 75.23 & 75.579 \\
\hline 4 & VIM (\%) & $3-5.0$ & 4.341 & 4.227 & 4.124 & 4.008 & 4.193 & 4.141 & 4.05 & 4.234 & 4.17 & 4.096 \\
\hline 5 & Stability (kg) & $\min 800$ & 1,566 & 1,552 & 1,507 & 1,463 & 1,537 & 1,515 & 1,507 & 1,529 & 1,515 & 1,507 \\
\hline 6 & $\begin{array}{l}\text { Melting rate } \\
\text { (Flow) (mm) }\end{array}$ & 02-Apr & 3.78 & 3.62 & 3.87 & 3.78 & 3.62 & 3.7 & 3.78 & 3.62 & 3.7 & 3.7 \\
\hline
\end{tabular}

Published By:

Blue Eyes Intelligence Engineering and Sciences Publication (C) Copyright: All rights reserved.

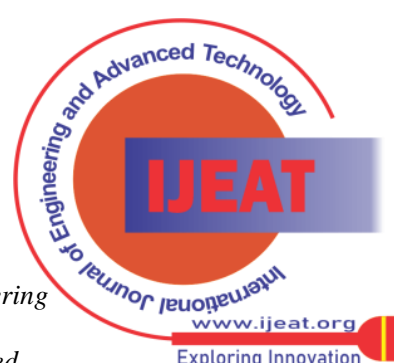
Exploring Innovation 


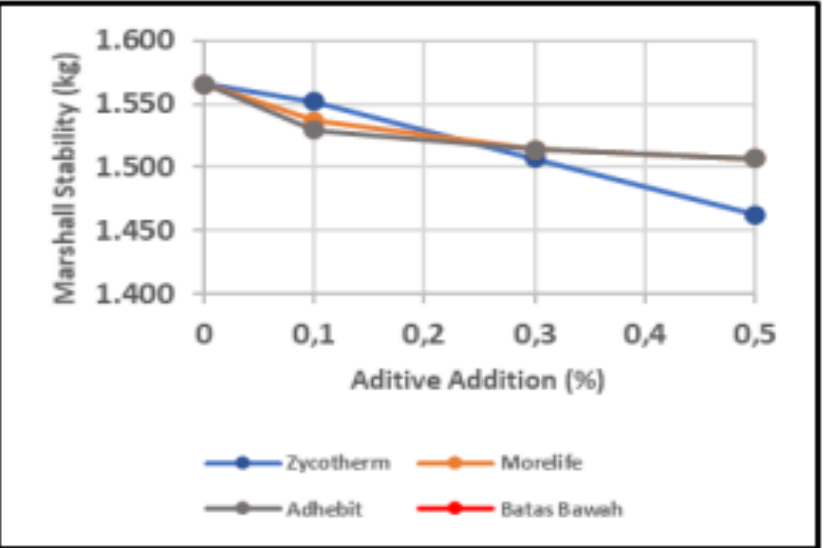

(a)

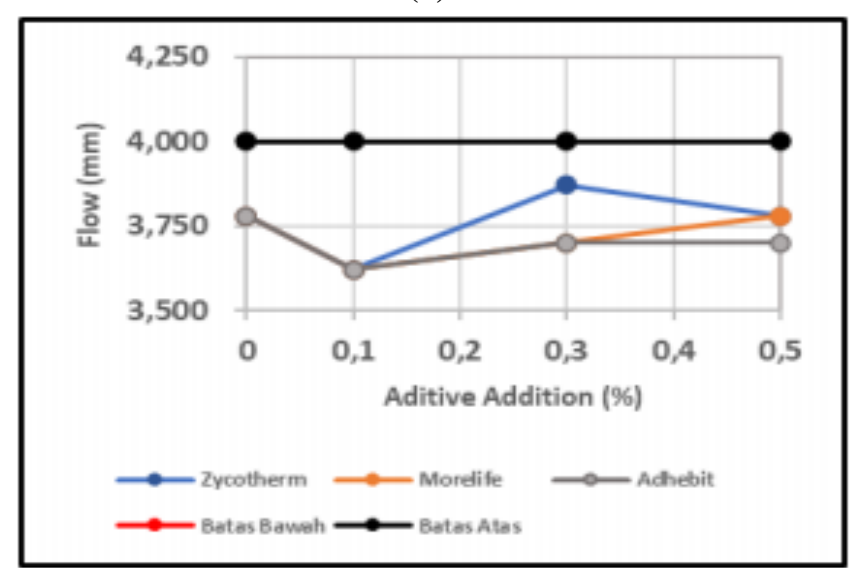

(b)

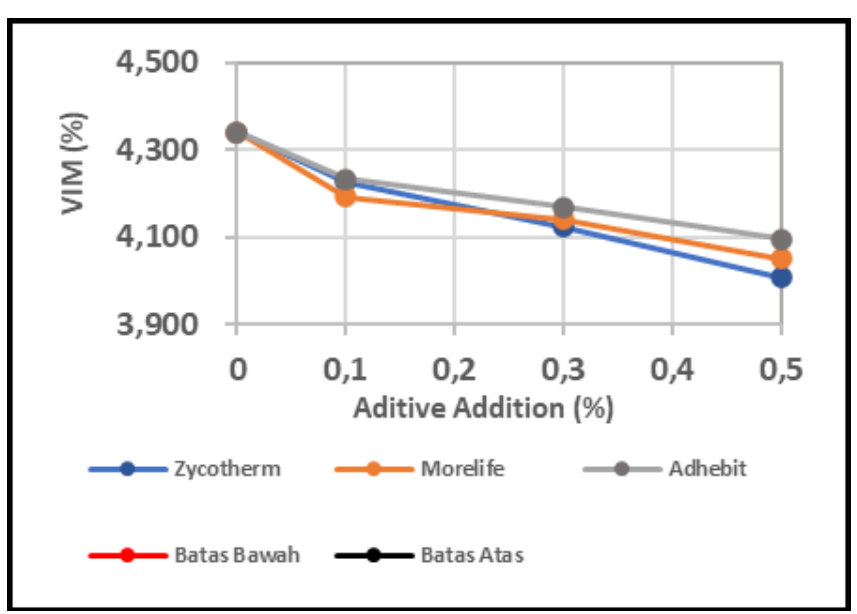

(c)

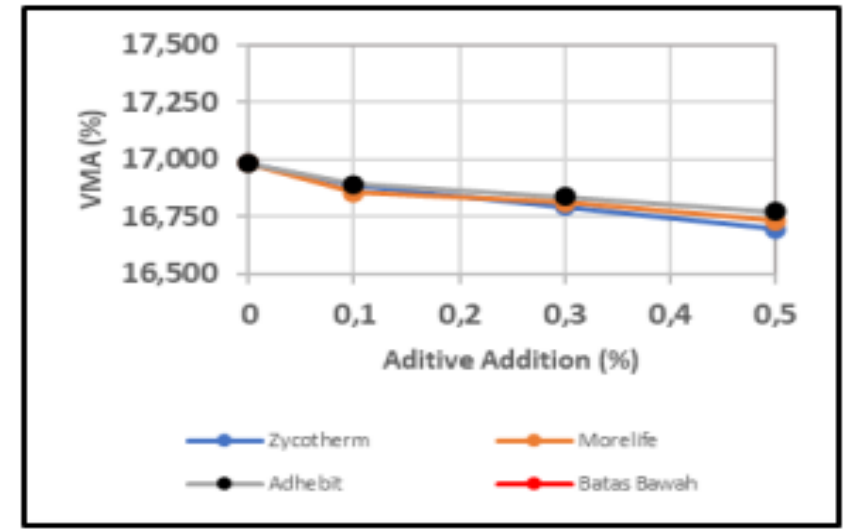

(d)

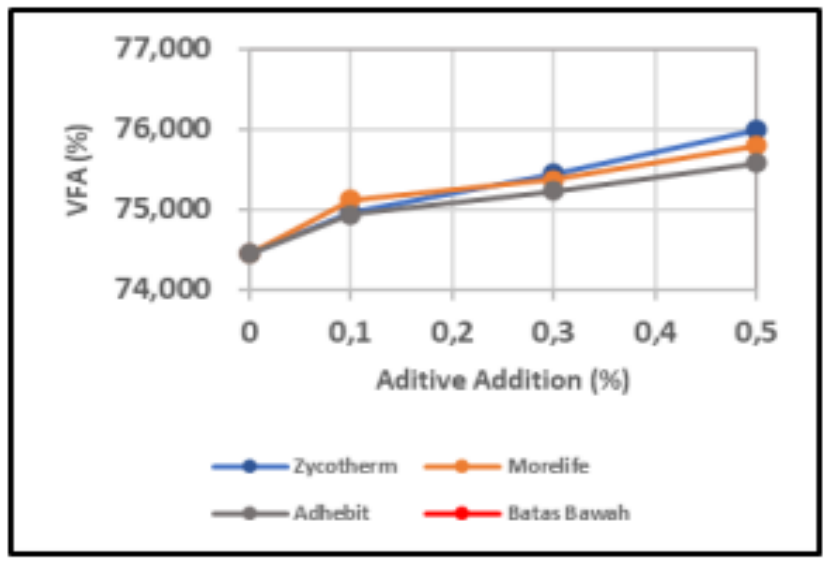

(e)

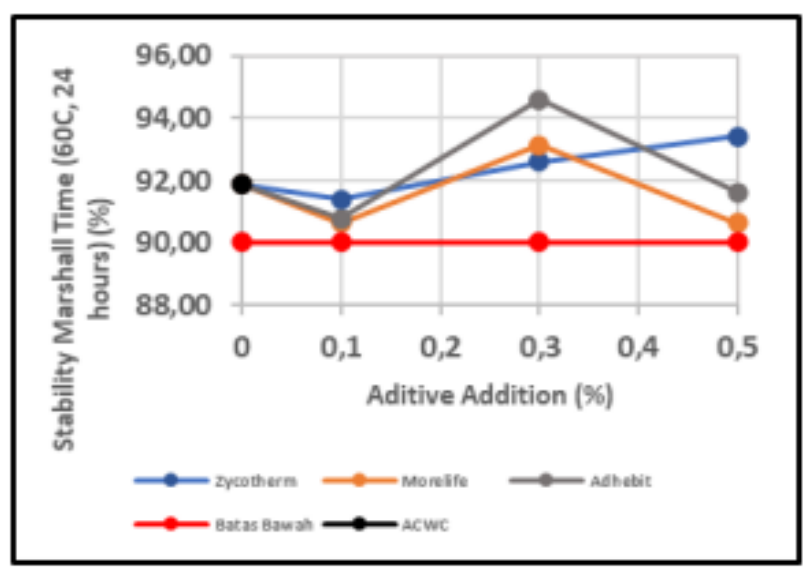

(f)

Figure 2 Relationship of Marshall Properties with additive additive increments

From The Table 6, the following results were obtained: Additional Levels of antistripping additives Zycotherm, Morlife and Adhebit in acwc mixture that meets specifications in the range of $0.1 \%, 0.3 \%$ and $0.5 \%$. The addition of these additives resulted in stability values, VIM and VMA decreased, VFA values increased in line with the increasing levels of additive additions but still at the specification limits. Flow value of ACWC mixture with antistripping additives fluctuates flow values in line with the increase in levels of additives Zycotherm, Morlife and Adhebit. This is in line with the results of research conducted by Rizal et al (2019), Jaya et al (2013) and Aminsyah (2014) which stated that the addition of antistripping additives in hot asphalt mixtures will lower the value of VMA, VIM and mixed stability. The best performance of Marshall Stability Value Time was demonstrated by the ACWC mixture with the addition of Adhebit additives at a rate of $0.3 \%$ with a Marshall Stability Residual value of $94.607 \%$ followed by the additive Zycotherm at a rate of $0.5 \%$ with a value of $93.433 \%$ and the additive Morlife at a rate of $0.3 \%$ with a value of $93.137 \%$.

Published By:

Blue Eyes Intelligence Engineering and Sciences Publication (C) Copyright: All rights reserved.

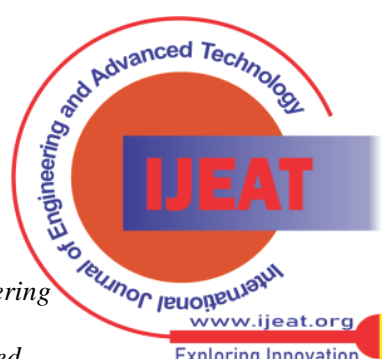
Exploring Innovation 
This is in accordance with the results of research conducted by Rizal et al (2019), Christopper et al (2016), Ruslan et al (2016), Sawaludin et al (2017), Jaya et al (2013), Aminsyah (2014) and Sembiring and Muis (2013) who stated that the addition of antistripping additives can improve the stability of the remaining Marshalls.

\section{F. Testing Marshall Soaked Modifications for ACWC with antistripping additives for Durability}

From the modified Marshall Immersion Test, the result show the overall value of ACWC mixed stability with the addition of additives decreased in line with the addition of additive levels and the duration of immersion, only in additives Zycotherm and Adhebit that experienced a reduction in the rate of decline in the soaking period of 3 to 7 days, while for Morlife additives the rate of decrease in stability was constant in line with the length of immersion almost the same as the ACWC mixture without the addition of additives. ACWC blend flow value with additive additions at additions of $0.1 \%, 0.3 \%$ and $0.5 \%$ rise in line with the length of immersion for all types and additive levels. The VIM, VMA and VFA values of the ACWC mixture fluctuate up and down but are not significantly in line with the length of immersion for all types and levels of additives.

\section{G. Time Stability Index Modified Marshall Soaking Test}

To see the performance of ACWC durability with antistripping additives are used two indicators namely Time Stability Index (IRS) and Stability Reduction Index including First Durability Index (IDP) and Second Durability Index (IDK). The average Marshall Test of the modification marshall test above can be calculated as The Time Stability Index (IRS) in Table 7. From Table 7 can be concluded Marshall Stability Value Time decreased in the soaking period of test objects day 1 to day 3, but experienced a decrease rate in the immersion period of day 3 to day 7 compared to ACWC mixture without the addition of additives for additives Zycotherm and Adhebit, while for additives Morlife decrease rate Stability The rest of Marshall is almost the same as ACWC mixture without additive addition. The best performance was demonstrated by ACWC mixture with the addition of additive Zycotherm at additive level of $0.5 \%$ with Marshall Stability Time value at 7th day soak at $89.34 \%$. This is in line with research conducted by Tahir and Setiawan (2009) which stated that the Value of The Time Strength Index decreases with the increasing length of immersion.

Table 7 Effect of Additive Type Usage on Residual Stability Index (IRS) Values on Length Variations of Soaking

\begin{tabular}{|c|c|c|c|c|c|c|}
\hline & & & \multicolumn{4}{|c|}{ Time Stability Index (IRS) (\%) } \\
\hline \multirow{3}{*}{ Aditive } & Content (\%) & Terms & \multicolumn{4}{|c|}{ Soaking Length } \\
\hline & & $(\%)$ & 0 days & 1 days & 3 days & 7 days \\
\hline \multirow{4}{*}{ Zycotherm } & 0.0 & $\min 90$ & 100.00 & 95.30 & 92.32 & 86.57 \\
\cline { 2 - 7 } & 0.1 & $\min 90$ & 100.00 & 94.74 & 89.95 & 87.08 \\
\cline { 2 - 7 } & 0.3 & $\min 90$ & 100.00 & 96.06 & 90.15 & 88.67 \\
\cline { 2 - 7 } & 0.5 & $\min 90$ & 100.00 & 95.43 & 90.86 & 89.34 \\
\cline { 2 - 7 } & 0.0 & $\min 90$ & 100.00 & 95.30 & 92.32 & 86.57 \\
\cline { 2 - 7 } & 0.1 & $\min 90$ & 100.00 & 95.65 & 91.30 & 85.99 \\
\cline { 2 - 7 } & 0.3 & $\min 90$ & 100.00 & 95.56 & 92.16 & 86.27 \\
\hline \multirow{4}{*}{ Mdhebit } & 0.5 & $\min 90$ & 100.00 & 94.68 & 91.13 & 84.24 \\
\cline { 2 - 7 } & 0.0 & $\min 90$ & 100.00 & 95.30 & 92.32 & 86.57 \\
\cline { 2 - 7 } & 0.1 & $\min 90$ & 100.00 & 93.69 & 89.32 & 86.41 \\
\cline { 2 - 7 } & 0.3 & $\min 90$ & 100.00 & 93.63 & 88.24 & 87.75 \\
\hline
\end{tabular}

Table 8 Results of First and Second Durability Index Testing with Additive Content Variation

\begin{tabular}{|c|c|c|c|c|c|c|c|}
\hline \multirow{3}{*}{$\begin{array}{c}\text { Additive } \\
\text { Content } \\
\text { Variation } \\
\text { \% }\end{array}$} & \multirow{3}{*}{$\begin{array}{c}\text { Immersion } \\
\text { Variations (Days) }\end{array}$} & \multicolumn{2}{|c|}{ ACWC+Zycotherm } & \multicolumn{2}{|c|}{ ACWC+Morelife } & \multicolumn{2}{|c|}{ ACWC+Adhebit } \\
\hline & & IDP & IDK & IDP & IDK & IDP & IDK \\
\hline & & r (\%) & a (\%) & r (\%) & a (\%) & r (\%) & a (\%) \\
\hline \multirow{5}{*}{$0,0 \%$} & 0 & & - & & - & & - \\
\hline & 1 & 4.702 & 4.37 & 4.702 & 4.37 & 4.702 & 4.37 \\
\hline & 3 & 1.492 & 2.13 & 1.492 & 2.13 & 1.492 & 2.13 \\
\hline & 7 & 1.437 & 1.64 & 1.437 & 1.64 & 1.437 & 1.64 \\
\hline & & 7.631 & 8.14 & 7.631 & 8.14 & 7.631 & 8.14 \\
\hline \multirow{2}{*}{$0,1 \%$} & 0 & & - & & - & & - \\
\hline & 1 & 5.264 & 4.89 & 4.348 & 4.04 & 6.311 & 5.86 \\
\hline \multicolumn{3}{|c|}{$\begin{array}{l}\text { Retrieval Number: } 100.1 / \text { ijeat.D23010410421 } \\
\text { DOI:10.35940/ijeat.D2301.0410421 } \\
\text { Journal Website: } w \text { ww.ijeat.org }\end{array}$} & 245 & \multicolumn{3}{|c|}{$\begin{array}{l}\text { Published By: } \\
\text { Blue Eyes Intelligence Engineerin } \\
\text { and Sciences Publication } \\
\text { (C) Copyright: All rights reserved. }\end{array}$} & \\
\hline
\end{tabular}


Durability of Asphalt Concrete (ACWC) Mixed with Antistripping Additive

\begin{tabular}{|c|c|c|c|c|c|c|c|}
\hline & 3 & 2.392 & 3.42 & 2.174 & 3.11 & 2.184 & 3.12 \\
\hline & 7 & 0.718 & 0.82 & 1.329 & 1.52 & 0.728 & 0.83 \\
\hline & & 8.374 & 9.13 & 7.850 & 8.66 & 9.223 & 9.81 \\
\hline \multirow{5}{*}{$0,3 \%$} & 0 & & - & & - & & - \\
\hline & 1 & 3.941 & 3.66 & 4.442 & 4.13 & 6.373 & 5.92 \\
\hline & 3 & 2.956 & 4.22 & 1.701 & 2.43 & 2.696 & 3.85 \\
\hline & 7 & 0.369 & 0.42 & 1.471 & 1.68 & 0.122 & 0.14 \\
\hline & & 7.266 & 8.30 & 7.614 & 8.24 & 9.191 & 9.91 \\
\hline \multirow{5}{*}{$0,5 \%$} & 0 & & - & & - & & - \\
\hline & 1 & 4.569 & 4.24 & 5.320 & 4.94 & 7.081 & 6.58 \\
\hline & 3 & 2.284 & 3.26 & 1.773 & 2.53 & 2.012 & 2.87 \\
\hline & 7 & 0.381 & 0.44 & 1.724 & 1.97 & 0.549 & 0.63 \\
\hline & & 7.234 & 7.94 & 8.818 & 9.44 & 9.642 & 10.08 \\
\hline
\end{tabular}

The average Marshall Test of the modification marshall test above can be calculated the First Durability Index (IDP) and the Second Durability Index (IDK) in Table 8. From the data in Table 8 obtained the first durability index (r) sample that uses the additive Zycotherm at a rate of $0.5 \%$ produces the lowest $r$ value of $7.234 \%$ at the duration of immersion 7 days, when compared with ACWC mixtures that use Morlife additives at a rate of $0.3 \%$ with a value of $r=7.614 \%$, Adhebit additives at a rate of $0.3 \%$ with a value of $r=9.191 \%$ and ACWC without additives with a value of $r=7.631 \%$. The test results showed that the second durability index (a) of samples using the additive Zycotherm at a rate of $0.5 \%$ resulted in the lowest a value of $7.94 \%$ at the duration of immersion 7 days, when compared with ACWC mixtures that use Morlife additives at a rate of $0.3 \%$ with a value of $8.24 \%$, Adhebit additives at a rate of $0.3 \%$ with a value of $9.91 \%$ and ACWC without additives with a value of $r 8.14 \%$.

The test results also showed that the first durability index (r) of mixed samples using the additive Adhebit yielded the lowest value at a rate of $0.3 \%$ on the 3rd to 7 th day with a value of $0.122 \%$, when compared to mixtures that use additives Zycotherm content of $0.3 \%$ at the value of $0.369 \%$, the mixture that uses morlife additives at a rate of $0.3 \%$ at the value of $1.471 \%$ and ACWC without additives with a value of $1.437 \%$. This proves that the addition of antistripping additives Adhebit and Zycotherm in the long term is able to slow the loss of strength / stability when done durability test. This can be seen from the performance of Adhebit and Zycotherm additives on the 3rd to 7th day soaks which are better than Morlife and ACWC additives without additive additions.

Table 8 data also showed that in the long run between the additiveless ACWC mixture and the ACWC mixture using morlife additives did not have a significant difference in strength loss. A significant difference in strength loss occurred between the ACWC non-additive mixture and the mixture that used the additive Zycotherm at a rate of $0.5 \%$ and Adhebit at a rate of $0.3 \%$.

The test results in Table 8 are in accordance with the research of Tahir and Setiawan (2009) which stated that the First Durability Index (IDP) and the Second Durability Index (IDK) generally experienced a loss of strength in line with the addition of the soaking length except on the 4th day soaking which showed increased strength.

Increasing Durability of AC WC mixture with the addition of additives in this study in accordance with the results of research conducted rizal et al (2019), Christopper et al (2016), Ruslan et al (2016), Sawaludin et al (2016 17), Jaya et

Retrieval Number: 100.1/ijeat.D23010410421

DOI:10.35940/ijeat.D2301.0410421

Journal Website: www.ijeat.org al (2013), Aminsyah (2014) and Sembiring and Muis (2013) stated that the addition of antistripping additives increases durability or durability due to water soaking.

\section{CONCLUSION}

From the results of data analysis conducted based on testing in this study, it can be concluded that the levels of addition of antistripping additives Zycotherm, Morlife and Adhebit in the mixture of ACWC that meet the specifications are in the range of $0.1 \%, 0.3 \%$ and $0.5 \%$. The addition of Zycotherm, Morlife and Adhebit antistripping additives to the ACWC mixture resulted in stability values, VIM and VMA falling, while VFA values increased in line with the addition of additive levels but still to the specification limit.

Acwc mixed flow value with antistripping additives fluctuate flow value in line with the increase in additive levels of Zycotherm, Morlife and Adhebit. The best Durability performance in the Marshall Immerson test was demonstrated by acwc mixture with the addition of Adhebit additive at $0.3 \%$ with Marshall Stability Time value of $94.607 \%$ followed by Zycotherm additive at $0.5 \%$ with value of $93.433 \%$ and Morlife additive at a rate of $0.3 \%$ with a value of $93.137 \%$ while from the soaking test the best performance modification is indicated by the additive Zycotherm at a rate of $0.5 \%$, followed by Morlife additives at $0.3 \%$ and Adhebit additives at $0.3 \%$.

The addition of antistripping additives at a rate of $0.1 \%$ in ACWC for all types of additives did not show significant results in improved durability performance due to asphalt peeling. From the analysis of laboratory research data obtained acwc mixture with the addition of additives Zycotherm produces the best durability improvement performance based on optimal marshall analysis and increased durability at a rate of $0.5 \%$ followed by additive Adhebit at a rate of $0.3 \%$, while in the additive Morlife although at a level of $0.3 \%$ able to show optimum marshall analysis in terms of increased durability in the long term did not show the expected performance.

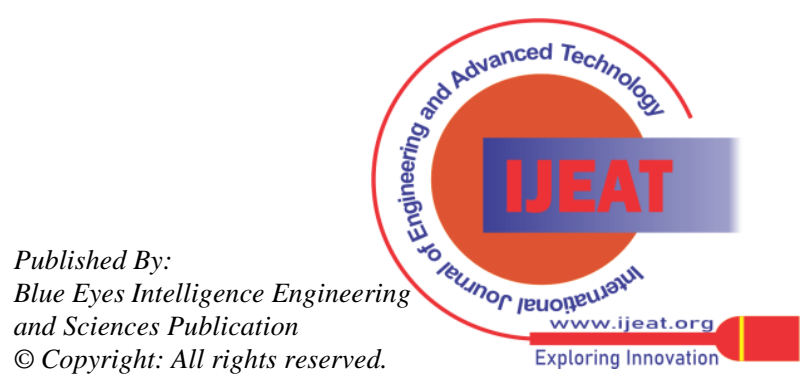




\section{REFERENCES}

1. AASHTO, (1998), Standard Specifications for Transfortation Materials and Methods of Sampling and Testing,Part I, Specifications, Nineteenth Edition, Washington D.C.

2. Aminsyah, M.,(2014) "Experimental Study of Addition of Antistripping Additives in Concrete Asphalt Mixture Performance (ACWC)" . Journal of Civil and Environmental Engineering Vol. 2 No. 4 ISSN: 2355-374X.

3. Asphalt Institute, (1993) Mix Design Methods for Asphalt Concrete and other Hot Mix Types, Manual Series No 2 (MS-2). Lexington, Kentucky,USA: Asphalt Institute.

4. Atkins, H.N., (1996), Highway Materials, Soils and Concretes, 3th Edition Prentice Hall, New Jersey.

5. National Standardization Body (2003). "Hot Paved Mix Testing Method with Marshall Tool".

6. Basir, A and Ramli, M,I.,(2005)," Performance Evaluation of Paved Mixed Durability Using Retona Supplemental Materials", Sriwijaya University, Palembang.

7. Christopper, Y et al (2016)," Influence of Antistripping Agent Additives on Asphalt Mixture", Journal of Engineering and Computer Science, Faculty of Civil Engineering, Krida Christian University.

8. Destiani, S., et al (2015)," Effect of Antistripping Addition on ACWC Concrete Asphalt Mixture with Split Material ex Palu and White Sand ex Muara Badak", University of 17 August 1945 Samarinda.

9. Hendarsin,L,S., (2000), "Highway Engineering Planning", Poltek, Bandung.

10. Iriansyah, U.S., (2003), " Hot Paved Mixture", Transportation Infrastructure Center.

11. Jaya, B., et al (2013);" Effect of Antistripping Supplemental Materials on Hot Asphalt Mixture Hot Rolled Sheet Wearing Course using local aggregate", Journal of Sustainable Technology (Sustainable Technology Journal) Volume 2 Number 2.

12. Ministry of Public Works and Public Housing, (2018a), "Circular Letter of Submission of General Specifications 2018 edition", Directorate General of Bina Marga.

13. Ministry of Public Works and Public Housing, (2018b), "Section 6.3 Specifications of Hot Paved Mixture", Directorate General of Bina Marga.

14. Oktafriyadi,R,. et al (2019)," Effect of Addition of Wetfix BE Additives on Mixing Pavement Of Asphalt Concrete Wearing Coarse (AC WC)", Faculty of Civil Engineering and Planning, Bung Hatta University.

15. Rizal, R.S., et al (2019)," Study of The Use of Wetfix Be On Superpave Graded Hot Mixed Asphalt Concrete", Scientific Journal of Applied Information Technology Volume 5, No. 2.

16. Ruslan, P., et al (2019)," Analysis of ASPHALT AC BC Mixed Plan using split ex Material. Hammer, sand ex. Mahakam and white sand ex. Kutai lama with the addition of Antistripping", Faculty of Engineering University august 17, 1945, Samarinda.

17. Rohith, N. and Ranjitha, J. (2013), "A Study On Marshall Stability Properties Of Warm Mix Aspahlt Using Zycotherm A Chemical Additive". International Journal of Engineering Research \& Technology (IJERT) ISSN 2278-0/81 Vol 2.

18. Sawaludin, et al (2017)," Use of Additive Antistripping Agent for Lataston Mixed Durability (HRS-WC)", Faculty of Civil Engineering, University of Tanjung Pura.

19. Sembiring, A.H. and Muis, Z.A., (2013), " The Effect of The Use of Agent Antistripping Variations on The Characterist of Aus-Coated Asphalt Concrete (ACWC). Department of Civil Engineering, University of North Sumatra.

20. Siswosoebroto, B.I., Karsaman, R.H., Setiadji, B.H., (2003) "Development of Cyclic Water Vapor Test for Durability Assessment of Bituminous Mixture for Pavement Material". Journal of the Eastern Asia Spociety for Transportation Studies, Vol.5.

21. Sukirman, S. (1999), "Pavement Bending the Highway." Bandung, Nova.

22. Sukirman, S. (2003), "Hot Mix Asphalt Concrete", Jakarta, Granite.

23. Susilowati, A., and Wiyono, E.,(2017)," Use of Antistripping Materials for Asphalt Concrete Mixture" Polytechnology Vol. 16 No.1 Department of Civil Engineering Jakarta State Polytechnic.

24. Tahir, A and Setiawan, A. (2009)," Asphalt Concrete Mixture Durability Performance is reviewed from compaction temperature variation factor and soaking duration". SMARTek Journal, Vol. 7, No.1.

\section{AUTHORS PROFILE}

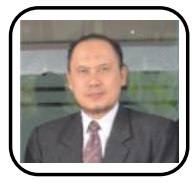

Bagus Hario Setiadji, Bachelor, Civil Engineering, Bandung Institute of Technology (1991 - 1996). Master, Highway Systems and Engineering, Bandung Institute of Technology (1997 - 2000). Doctor, Highway Engineering, National University of Singapore (2004 - 2010).

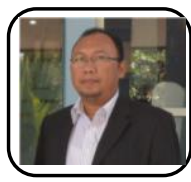

Jati Utomo Dwi Hatmoko, Bachelor, Civil Engineering, Diponegoro University (1993 - 1998). Master, Civil Engineering, Newcastle University, UK (2002 - 2003). Doctor, Civil Engineering, Newcastle University, UK (2003 - 2008).
Sena Kuswara, Master Program of Civil Engineering, Diponegoro University, Semarang, Indonesia.

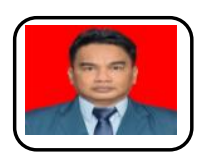

Retrieval Number: 100.1/ijeat.D23010410421

DOI:10.35940/ijeat.D2301.0410421

Journal Website: www.ijeat.org

Published By:

Blue Eyes Intelligence Engineering and Sciences Publication 